higher education is increasing as quickly as at present, and when the government has itself provided for an increase in the cost of what is called "non-advanced further education" (vocational courses of various kinds), it makes no sense at all that, for the first time in British history, access to universities and to higher education in general should be restricted by decree of the Department of Education and Science.

Not even the British Government can be content with this illiberal state of affairs. Going down in history (and into a general election, now not more than two years away) with such a reputation cannot be much of a comfort. But those who will be permanently damaged are not the politicians responsible for these developments but educational institutions, universities and polytechnics, and the students whom they are now prevented from teaching. This is why it is simply not good enough that those who might be thought to be responsible for the long-term interests of the universities should for practical purposes be sitting on their hands, doing nothing to bring about the structural changes in higher education on which survival must ultimately depend. The University Grants Committee, which is technically responsible for foisting student quotas on its dependants, shows very little sign of advocating the changes in the mechanisms of financial support for universities that will be necessary if flexibility is ultimately to be achieved. The Committee of Vice-Chancellors and Principals, united (and successful) in its efforts in the past six months to establish that only the government can meet the cost of firing academics from tenured posts, is constitutionally incapable of pressing for arrangements that would encourage diversity within the university system. And the polytechnics, the other important sector of British higher education, are uncomfortably squeezed financially between local and central government yet as firmly isolated as ever from the rest of higher education. They suffer from the awkward circumstance that their bills are paid by local authorities, which are then promptly reimbursed by the central government. After two years of argument, the central government has wrested back only a token of control.

The folly of these arrangements is already clear. The student quotas to which universities are being required to plan for the academic year beginning eighteen months from now will ensure that almost all universities become smaller and thus make less efficient use of their capital equipment. Some will become so much smaller that they will be forced to abandon teaching in many fields and thus cease to be universities except in name. The obvious solution (see Nature 18 February, p.541) is to devise a mechanism that will enable the total cost to the government of supporting universities and their students to be defined in advance, and limited, without restricting the capacity of universities to perform the social functions of educating young people for which they were originally created. Such a device would also provide universities with an incentive towards diversity; universities fearful of their capacity to compete for students with, say, Oxbridge would be faced with the prospect either of making themselves distinctive or going out of business. Universities least able to compete would also find themselves persuaded by objective pressures to teach more economically or even to form associations among themselves whose effect would be an economical division of labour. What would be wrong with such a state of affairs except the unwillingness of individual universities to acknowledge that while they are titularly equal, some are more equal than others?

The practical obstacle to such an arrangement, however, is not so much the unwillingness of universities to acknowledge what must be done as the division between the two halves of the binary system - the universities on the one hand and the polytechnics created as a kind of academic counterforce by the late $\mathrm{Mr}$ Anthony Crosland in 1966. Both halves are now under severe pressure but independently. When academics are fired or teaching departments closed in either half of the binary system, it is in principle possible to ensure that the weakest will be the first to go. But there is no conceivable means by which the performance of people or departments in one half of the system can be compared with that of their equivalents in the other half. As a result, there is every likelihood that the decisions now being made by universities and polytechnics separately are inconsistent, even nonsensical. Few among British taxpayers (many of whom are academics) dispute the need that the government should contain its public expenditure, but it is just as important that the cash limits now being enforced for higher education should be accomplished in the most economical way - that which will yield the greatest benefit for whatever funds there are to spend. After a long period during which the government has had to fight the local authorities for a measure of central control of the polytechnics, it is understandable that it should lack the stomach for trying to set up some common framework within which both kinds of institutions could function. But nothing less than that will meet the present urgent need.

\section{Turkish illiberality}

\section{The scientific community must make up its mind how to help members denied freedom.}

The sad case of Dr Yeter Ogelman (see Nature 25 February, p.638 and this issue, p.231), the Turkish scientist who spent more than half of last year in a Turkish gaol, is still unresolved. At the resumed hearing of her case last week, Dr Oggelman was neither acquitted nor found guilty of the charge that her part in the organization of a women's rights campaign in the early 1970s was subversive of the new social order in Turkey. The result is that the charge will remain in abeyance, allowing the authorities to breathe new life into it whenever they choose. Meanwhile, $\mathrm{Dr}$ Ögelman remains dismissed from her post in the physics department of Cukorova University.

What, in these circumstances, should the scientific community do? The first temptation is to protest that it is thoroughly illiberal, and a serious infringement of what has come to be considered ordinary people's rights, that a person should be hounded and imprisoned as Dr Ögelman has been. The difficulty, unfortunately, is that the scientific community is not competent to raise such a complaint. For Dr Ogelman has been prosecuted not because she is a physicist but because of her part in an organization intended to secure rights for women in a society in which these have recently been denied. So there is no cause for the scientific community or its academies to stand up and complain at Dr Ögelman's treatment. Exactly the same principle applies to other states, of which there are now all too many, in which scientists and others must work under conditions in which personal liberty is unreasonably restricted. Other people's laws may be distasteful, but they are, after all, laws from which people cannot be exempted because they are scientists.

So is there nothing that can be done for Dr Ogelman, and for the growing band of scientists imposed upon by martial law in Poland (and for that matter Argentina)? Formal protests are inappropriate - which is not to say that individuals should not be free to support other organizations that are competent to complain - but practical help is both appropriate and likely to be welcome. The obvious and shining example of what can be accomplished is that of the 1930s, when many of those for whom life had become intolerable in central Europe were able to find jobs and continue their careers in the West. Now, the plight of those whose freedom is constrained is rarely as desperate as in the years before the Second World War, and there is also something in the view that the cause of personal liberty itself will be helped if those in trouble with the authorities stay in their own countries. But the provision of refuges overseas is not the only practical help that can be offered and that is likely to be welcome. People who have lost their jobs can be helped to remain active in scientific work even from a distance. Grant-making bodies and those who organize international conferences can usefully consider the interests of their colleagues who are deprived of freedom. Is it too much to ask that the scientific community, rightly standing aloof from the internal affairs of states elsewhere, should nevertheless more systematically consider how to help those of its members who are in trouble? 